\title{
Zoobenthic biodiversity, biomass and abundance at Adelaide Island, Antarctica
}

\author{
David K. A. Barnes ${ }^{1, *}$, Simon Brockington ${ }^{2}$ \\ ${ }^{1}$ Biological Sciences Division, British Antarctic Survey, Natural Environment Research Council, High Cross, \\ Madingley Road, Cambridge CB3 0ET, United Kingdom \\ ${ }^{2}$ Svitzer Ltd, Morton Peto Road, Great Yarmouth, Norfolk NR31 0LT, United Kingdom
}

\begin{abstract}
The waters surrounding Antarctica are amongst the most isolated large areas of continental shelf, cut off for about 15 to 30 million yr by both deep water and the oceanographic barrier of the Polar Frontal Zone (PFZ). Although certain taxa are notably absent, shelf seabed richness (of the mostly endemic species) can be very high. Most of Antarctica's shallow shelf lies between 67 and $72^{\circ} \mathrm{S}$, although virtually all the growing southern polar marine biology literature has been carried out to the north or south of this. Here we report one of the first, and the most detailed, quantitative studies of benthic faunal abundance, diversity and biomass from within this latitudinal belt (at Adelaide Island, Antarctic Peninsula). Representatives of 16 phyla, 25 classes, 34 orders and at least 75 species were found in the 40 samples of $0.25 \mathrm{~m}^{2}$ area. This is rich, especially for polar localities described to date. Faunal abundance increased logarithmically from $<100$ to $>10000$ individuals $\mathrm{m}^{-2}$ from the intertidal to $35 \mathrm{~m}$ respectively. Annelids and bryozoans were the most numerous, and cryptofauna (such as these 2 phyla) exerted a major influence on both patterns and absolute values of diversity. Subtidal biomass increased from 500 to $10000 \mathrm{~g} \mathrm{~m}^{-2}$ at 3 to $35 \mathrm{~m}$ respectively and is, overall, the highest for any polar locality within the 0 to $40 \mathrm{~m}$ depth range. The echinoid Sterechinus neumayeri was the principal cause of these high values as it dominated biomass at all subtidal depths, although molluscs (particularly the limpet Nacella concinna) were important in the shallows. Striking subtidal zonation was apparent, demarked by both inter- and intra-specific characteristics. We suggest that faunistic bathymetric organisation essentially forms 3 zones comprising different suites of species and is also demarked by the population structure of the species $S$. neumayeri. Not only do the species $S$. neumayeri and $N$. concinna show strong zonation in occurrence but also their grazing activity is probably a strong agent producing similar patterns in cryptobenthos (through removal of recruits). We propose a general schematic (a diagram) of zonation as declining in the littoral southwards towards the PFZ and increasing in the subtidal southwards from the PFZ.
\end{abstract}

KEY WORDS: Polar $\cdot$ Community $\cdot$ Marine $\cdot$ Zonation $\cdot$ Echinoids $\cdot$ Hotspot

\section{INTRODUCTION}

Coastal benthos have been fundamental in the construction and testing of major ecological and evolutionary theories for many decades. The continental shelf seabed has, in comparison with any other region, the most prolific fossil record and arguably the oldest living fauna (Valentine 1973, Jablonski \& Bottjer 1990), the largest number of higher taxa and different body plans represented, and amongst the most productive and complex systems (Barnes \& Hughes 1999). Explanations of patterns of biodiversity, biomass and abundance of seafloor fauna still raise considerable debate at global, regional or even local level and are clearly complex (Gray 2001). Benchmark early explanations of wide-scale geographic trends were on bivalves (Stehli et al. 1967) and corals (Stehli \& Wells 1971) and Sanders' (1968) California transect from shallow to deep water. Only relatively recently, however, have highly robust data sets been presented with attempts 
at correcting for many confounding factors. Latitudinal clines have again become the focus of attention, especially in the more intensely sampled northern hemisphere waters. Roy et al (1998) found a strong poleward decline in gastropod species on both Pacific and Atlantic American coasts as Clarke \& Lidgard (2000) found in north Atlantic bryozoans. In contrast, overall latitudinal or longitudinal patterns are not clear in the southern hemisphere (Clarke 1992), in part due to the lower shelf biodiversity (Brey et al. 1994). Although construction of global data for some taxa, e.g. bivalves (Crame 2000), is advanced, there is a paucity of sampling or knowledge of others. The southern hemisphere differs considerably from the northern in that water occupies considerably more surface area, and at some latitudes, there is only water whereas at others there is only land. At extreme latitudes, the polar regions differ in topography (land vs sea), age, depth and substratum.

Despite the enormity of the Antarctic coastline, little quantitative sampling of benthos has been carried out in inshore waters (Arntz et al 1994). High Antarctic assemblages may have very low rates of colonisation, be dominated by sponges and their predators, and are structured by anchor ice (Dayton et al. 1970, 1974). In the maritime Antarctic islands, in contrast, there is a diverse range of taxa and whilst recruitment to assemblages is slow, colonisation is continuous (though seasonal in some taxa) and it is principally summer icescour rather than winter ice encasement that structures communities (Barnes 1995, Stanwell-Smith \& Barnes 1997). Between the high Antarctic and maritime islands are $15^{\circ}$ of latitude where our knowledge is rudimentary with the exception of a few sites, such as King George Island, the Palmer Archipelago or Kapp Norvegica (Gallardo \& Castillo 1969, Zamorano 1983, Rauschert 1991, Klöser et al. 1993, 1994a,b). In particular, between 67 and $72^{\circ}$ latitude (where most of Antarctica's shallow shelf lies), only at the Vestfold Hills has shallow shelf fauna even been studied in moderate detail (Kirkwood \& Burton 1988, Tucker 1988). There have been and are, however, some extensive deep-water study programmes, particularly in the Weddell Sea (Voß 1988, Galéron et al. 1992, Gutt \& Starmans 2001). The intense and frequent scouring that such work has reported, even at several $100 \mathrm{~m}$ depth, in both the Antarctic and Arctic (Gutt et al. 1996, McCook \& Chapman 1997, Gutt \& Starmans 2001), can only allude to ice-mediated disturbance in shallow water. Ice effects seem likely to reach maximal influence in the intertidal region, which is scoured by floating ice during the summer and encased by an icefoot during winter.

In the current study we undertook a quantitative sampling programme of mega-, macro- and crypto- benthos at a previously unsampled southerly latitude and region. We hypothesise that biodiversity, biomass and abundance all increase monotonically with increasing depth. This is because we consider ice-scour (which decreases dramatically with depth) as the dominant influence on biodiversity, biomass and abundance. We also hypothesise that bathymetric trends in benthos do not vary with taxonomic level and attribute considered. Taxa dominating scale or structure of communities are used for special discussion, as are scale, pattern and process effects on southerly faunal zonation.

\section{MATERIALS AND METHODS}

Study site. Samples were collected adjacent to the British Antarctic Survey Research Station on Rothera Point at the south-west end of Adelaide Island, west Antarctic Peninsula. Mean annual salinity generally varies little with depth throughout the year. Hyposaline lens formation in the upper water column was observed on a limited number of occasions at the height of the austral summer, but never reduced salinity of the upper $10 \mathrm{~m}$ by more than 1 psu relative to the underlying water column (but other depths-which were untested-may have become more dilute). The annual sea temperature range varied between $\sim-1.9$ and $\sim+1.0^{\circ} \mathrm{C}$. The sea surface freezes to form fast ice for several months over winter each year. At the point of fast ice connection to the shore an ice foot builds up and encases the full $2 \mathrm{~m}$ of the intertidal zone. Formation of anchor ice was also observed on 1 occasion (winter) during the 26 mo observation period. This subsurface ice attached to the seabed formed gradually over 5 d in July 1998. Coverage was complete (locally) to $4 \mathrm{~m}$, and more patchy down to $8 \mathrm{~m}$ depth. Scour by brash ice and icebergs was often observed, and both intensity and frequency of scour decreased with depth.

Protocol. The abundance and biomass of benthic taxa were assessed in January and February (austral summer) of 1998 along a transect running south from Cheshire Island, Adelaide Island $\left(68^{\circ} \mathrm{S}, 68^{\circ} \mathrm{W}\right)$. The substratum profile, type and characteristic organisms are shown in Fig. 1. Mega- and macrofaunal sampling was carried out using SCUBA. Divers collected all nonencrusting biota within 2 replicate $0.25 \mathrm{~m}^{2}$ quadrats at $3,6,9,12$ and $20 \mathrm{~m}$, and 1 quadrat collection was made at $35 \mathrm{~m}$. The fauna in 30 replicate quadrats was examined from the intertidal zone. Care was taken to ensure all cryptic macrofauna was recovered by systematic removal of overlying rocks. Smaller non-encrusting species (e.g. terrebellid polycheates) were carefully removed using forceps. All material was placed into mesh bags underwater and returned to the laboratory 
where samples were sorted to the lowest taxonomic level possible; at least order and, where possible, species. As well as counting all individuals all organisms were weighed (wet mass). Particular attention was paid to the echinoid Sterechinus neumayeri, which was considered to have an important role in the community. The size of a minimum of 80 randomly selected individuals of $S$. neumayeri was measured from each depth using Vernier callipers. The shape of the size distributions was recorded (as a plot) together with the mode values.

Encrusting cryptofauna was measured by collecting all boulders, cobbles and pebbles in quadrats (again using SCUBA). These were examined in the laboratory using a binocular microscope, and all colonists counted. Colonies of taxa such as bryozoans and hydroids were each counted as 1 individual. Biomass of cryptofauna was estimated for each taxon from previous (same species) mass estimates of colonists from another Antarctic locality (Barnes 1995). The age structure and mass at age of some of the common encrusting species was taken from Barnes \& Arnold (2001a). For ease of comparison megafauna and cryptofauna biomass and abundance values were multiplied to provide estimates per $\mathrm{m}^{2}$. Diversity of assemblages was estimated using the Shannon-Wiener information functions $H^{\prime}$ and Pielou's $J^{\prime}$ at species, order, class and phylum levels on abundance data. We appreciate this has 2 drawbacks due to the wide size range of animals involved and the combination of colonial and unitary taxa. Nevertheless we consider that it will be most useful to other researchers in this form as most comparable data we found in the literature has been treated similarly.

\section{RESULTS}

The fauna at the high latitude, shallow marine study site was taxonomically rich; representatives of 16 phyla, 25 classes, 34 orders and at least 75 species (Table 1) were present. Echinoderms, bryozoans, sponges and molluscs were the major contributors. Values of diversity (Shannon $H^{\prime}$ ) ranged from 0.1 to 0.9 and formed relatively simple patterns with depth and taxonomic level (Fig. 2). Although Shannon $H^{\prime}$ values were calculated on abundance data, recalculation with biomass data showed the same pattern with slightly reduced values. Cryptofauna (mainly annelids and bryozoans) exerted a major influence on both patterns and absolute values of diversity, so total fauna and mega/ macrofauna alone are plotted separately in Fig. 2. Values of total faunal diversity were greatest at the lowest taxonomic level (species) and progressively decreased to the highest taxonomic level (phylum). In contrast, mega/macrofaunal diversity was lowest at species rank but proportionally increased with taxonomic level. Shannon $H^{\prime}$ values of mega/macrofaunal diversity were uniformly lower than total fauna diversity at species rank. At higher taxonomic levels, however, Shannon $H^{\prime}$ values of mega/macrofaunal diversity were higher (apart from $3 \mathrm{~m}$ ) than total faunal diversity values. The overall patterns of total faunal diversity were broadly similar from phylum to species, but changes with depth were less at higher taxonomic levels. At all levels diversity was low at the shallowest sites.

Trends of evenness (Shannon $J^{\prime}$ values not shown) followed similar patterns to those of diversity, with respect to depth and taxonomic level. Total fauna evenness fell in the range 0.3 to 0.9 for all samples (values were similar at higher taxonomic levels although the lowest values were encountered at phylum level). Mega/macrofaunal evenness showed the same increase with taxonomic level as recorded for $J^{\prime}$ values, and macrofaunal evenness was greater than total evenness over the whole depth range at phylum level.

As well as the large number of taxa present, numbers of individuals were high. Abundance of phyla varied, even within depth horizons by nearly 5 orders of magnitude. Annelids and bryozoans were most numerous, occurring in 1000 s per $\mathrm{m}^{2}$ whilst flatworms, sipunculans and priapulans were never more abundant than 10 per $\mathrm{m}^{2}$. Most phyla were, however, present in $10 \mathrm{~s}$ per $\mathrm{m}^{2}$. Brachiopods and priapulans showed no distinct patterns with depth but other phyla exhibited 1 of 3 main patterns (Fig. 3). Many, including the 4 overall most numerous phyla, initially sharply increased with depth but all reached asymptotes before $35 \mathrm{~m}$. The second pattern was of mid-depth abundance and fewer individuals $<6 \mathrm{~m}$ and $>20 \mathrm{~m}$ (Fig. 3b) shown by the nemerteans and cnidarians amongst others. The mollusc data was scattered-they were most numer-

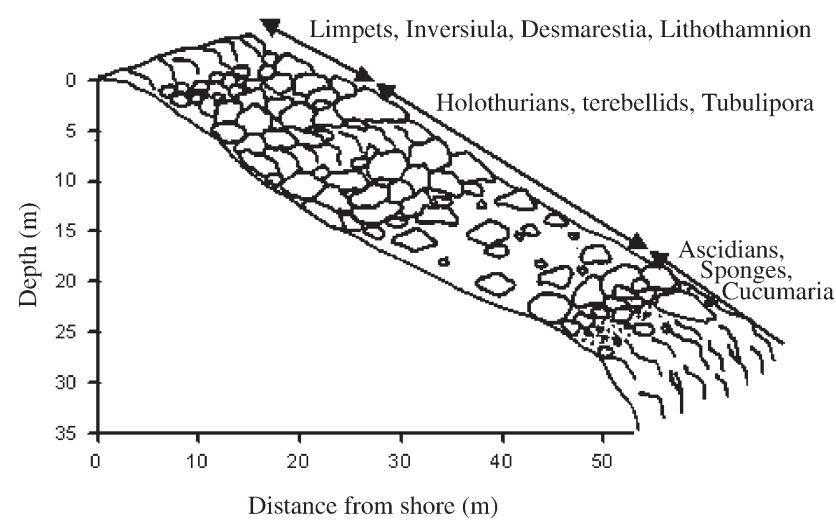

Fig. 1. Shore profile and substratum of study locality at Adelaide Island, Antarctica. Characteristic macro-organism species are shown in their zones of abundance 
Table 1. Various species. Taxa recorded between intertidal* and $35 \mathrm{~m}$ depth at Adelaide Island, Antarctica. Terminology and listing order follows Barnes (1998). Only a single class is recognised in each of the Priapula and Entoprocta (and only a single order in the latter) which are shown as (-)

\begin{tabular}{|c|c|c|c|}
\hline Phylum & Class & Order & Species \\
\hline \multirow[t]{5}{*}{ Porifera } & Demospongiae & Axinellida & Homaxinella sp. \\
\hline & & Dendroceratida & Dendrilla antarctica \\
\hline & & Haplosclerida & Haliclona dancoi, Haliclona sp.1, Haliclona sp.2 \\
\hline & & Poecilosclerida & Mycale acerata \\
\hline & & Spirophorida & Chinachyra sp.1, Tetilla antarctica \\
\hline \multirow[t]{2}{*}{ Cnidaria } & Anthozoa & Alcyonacea & Urticiniopsis antarctica, Alcyonium sp. \\
\hline & Hydrozoa & Leptothecata & Halecium sp., Symplectoscyphus sp. \\
\hline Platyhelminthes & Turbellaria & Tricladida & 1 unknown species \\
\hline Priapula & - & Priapulida & 1 (maybe 2) unknown species \\
\hline Nemertea & Anopla & Heteronemertea & Parbolasia antarctica, Tetrahymena sp.?* \\
\hline Nematoda & Unknown & Unknown & Unknown species* ${ }^{*}$ \\
\hline Sipuncula & Unknown & Unknown & Unknown species ${ }^{*}$ \\
\hline \multirow[t]{3}{*}{ Annelida } & Polychaeta & Phyllodocida & Nereis sp. ${ }^{*}$, Nephtys sp. \\
\hline & & Spionida & $\sim 4$ unknown species \\
\hline & & Terrebellida & 1 unknown species \\
\hline \multirow[t]{5}{*}{ Mollusca } & Gastropoda & Docoglossida & $\begin{array}{l}\text { Nacella concinna }{ }^{*}, \text { Laevilitorina caliginosa }{ }^{*}, \text { Iothia } \\
\text { coppingeri, Magarella antarctica, unknown species }\end{array}$ \\
\hline & & Nudibranchia & Charcotia granulosa, Tritoniella belli \\
\hline & Bivalvia & Pteriida & Limatula hodgsoni \\
\hline & & Arcida & Lissarca sp., unknown species \\
\hline & Polyplacophora & Ischnochitonida & Nutallochiton mirandus \\
\hline \multirow[t]{2}{*}{ Crustacea } & Copepoda & Harpacticoida & Tigriopus angulatus*, unknown species \\
\hline & Malacostraca & $\begin{array}{l}\text { Amphipoda } \\
\text { Isopoda }\end{array}$ & $\begin{array}{l}\text { Bovalia gigantean, Paraceradocus gibba, unknown species* } \\
\text { Glyptonotus antarcticus, } 1 \text { unknown species }\end{array}$ \\
\hline \multirow[t]{2}{*}{ Chelicerata } & Arachnida & Acariformes & Unknown species \\
\hline & Pycnogona & Pycnogonida & Nymphon sp. \\
\hline Entoprocta & - & - & Barentsia sp. \\
\hline \multirow[t]{2}{*}{ Bryozoa } & Stenolaemata & Cyclostomatida & Disporella sp., Tubulipora sp., Lichenopora sp. \\
\hline & Gymnolaemata & Cheilostomatida & $\begin{array}{l}\text { Aimulosia Antarctica, Arachnopusia inchoata, Celleporella } \\
\text { antarctica, Celleporella bougainvillea*, Fenestrulina rugula, } \\
\text { Hippadanella inerma, Inversiula nutrix, Micropora } \\
\text { brevissima, Smittina sp., Smittina rogickae, Xylochotridens } \\
\text { rangifer }\end{array}$ \\
\hline Brachiopoda & Articulata & Terebratulida & Liothyrella uva \\
\hline \multirow[t]{4}{*}{ Echinodermata } & Asteroidea & Phanerozonida & Odontaster validus, Perknaster fuscus, Porania antarctica \\
\hline & Echinoidea & Echinoida & Sterechinus neumayeri \\
\hline & Holothuroidea & Dendrochirotida & Cucumaria antarctica, Psolus antarctica, 3 unknown species \\
\hline & Ophiuroidea & Ophiurida & Ophiurontus victoriae, 1 unknown species \\
\hline Chordata & Ascidiacea & Phlebobranchia & 1 unknown species \\
\hline
\end{tabular}

ous at shallow depth but high again at the deepest sample (35 m).

Overall faunal abundance was high and increased by nearly an order of magnitude from 3 to $35 \mathrm{~m}$. Faunal abundances in the intertidal zone were variable but low (between 0 and $30 \mathrm{~m}^{-2}$ ) and SDs were of considerably higher magnitude than means after 30 samples. The variation in abundances from the intertidal to the subtidal zone was much greater and dwarfed any subsequent increase with depth. Similar patterns were evident for overall biomass though the scale of increase differed. Biomass increased over nearly 2 orders of magnitude from 3 to $35 \mathrm{~m}$, but observations suggested a 3 order of magnitude change from the intertidal to $3 \mathrm{~m}$.
In strong contrast to relative abundance, echinoderms dominated biomass at all depths from 3 to $35 \mathrm{~m}$ (Fig. 3c). Patterns of biomass with depth for most phyla were similar to those of abundance. Echinoderm mass increased steadily with depth over the entire transect, although from 3 to $12 \mathrm{~m}$ this was due almost entirely to a single species: the regular echinoid Sterechinus neumayeri. Furthermore from 20 to $35 \mathrm{~m}$ echinoderm biomass was contributed almost entirely by holothurians, mainly Cucumaria antarctica. The biomass of a number of other phyla also peaked at the deeper sample depths (Fig. 3c). Mollusc biomass (the second greatest overall), as with abundance, decreased steadily with depth after a peak at $6 \mathrm{~m}$ caused principally by a 
Fig. 2. Various species. Diversity (Shannon $H^{\prime}$, base 10) of macroorganisms at various taxonomic levels with depth at the study locality. The symbols are total $(\bullet)$ and total
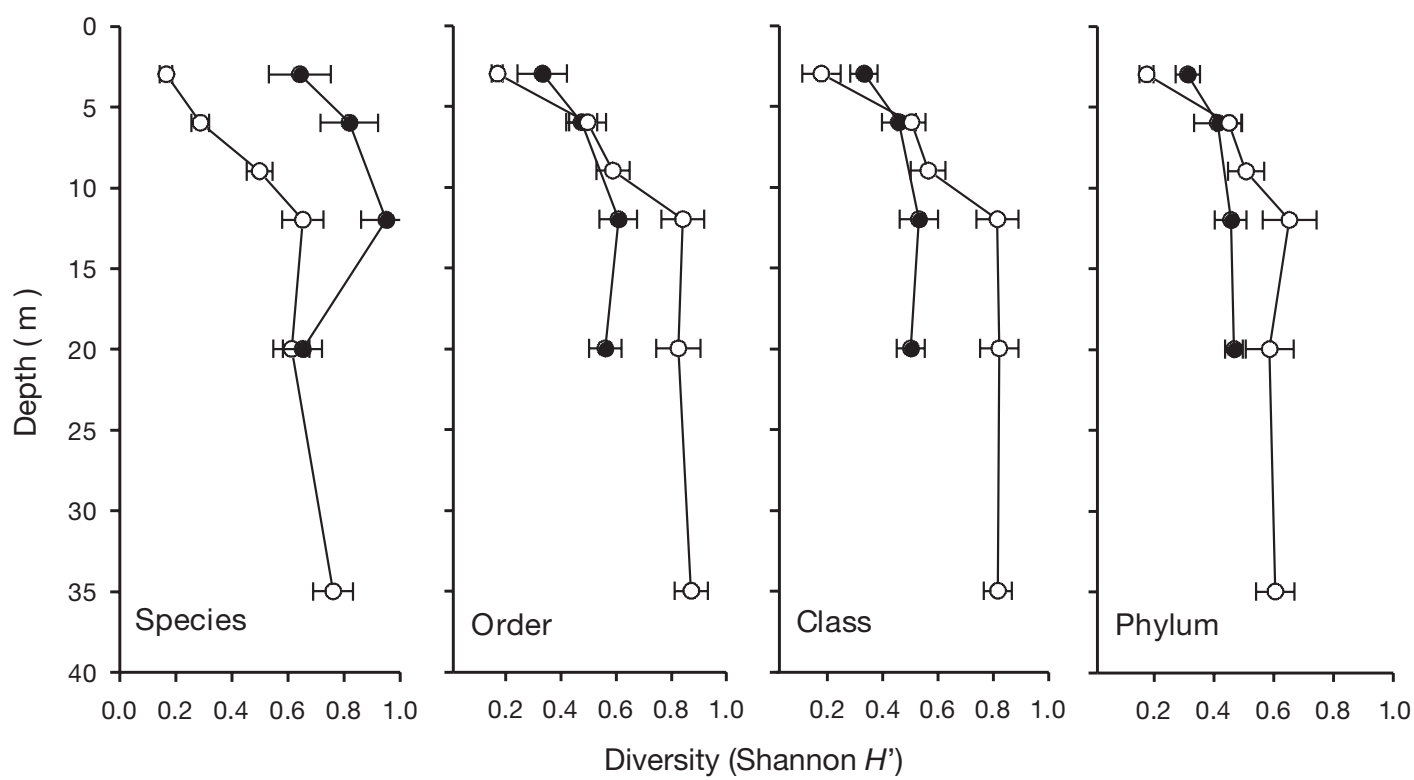

reduction in population density of the limpet Nacella concinna. Annelids and Porifera were notable in being major contributors to both faunal abundance and biomass. Although 2 orders of Annelida were numerically dominant over the entire range, 1 order (Terrabelida) was responsible for the biomass peak at $20 \mathrm{~m}$.

Fauna could essentially be categorised into 3 scales of biomass, with representatives of each category separated by approximately 1 order of magnitude at any particular depth. At intermediate levels of biomass (5 to

Fig. 3. Various species. Abundance and biomass of macro animal phyla with depth at the study locality. Abundance plots $(a, b, c)$ are split by type of pattern with bathymetry. Taxa are indicated on plots or in legend. Raw data (logplot of $x+1$ ) of abundance-depth relationships for annelids, bryozoans, chelicerates, chordates, cnidarians, crustaceans, echinoderms, entoprocts, nemerteans, sipunculans and sponges all have significant quadratic functions in which all $\mathrm{r}^{2}>54.7 \%$, ANOVA, $F>6.2, \mathrm{p}<0.05$. Biomass of 6 selected taxa are shown (d), labelled on plot. Raw data of biomass-depth relationships for annelids, bryozoans, chordates and sponges all have significant quadratic functions in which all $\mathrm{r}^{2}>64.3 \%$, ANOVA, $F>8.7$, $\mathrm{p}<0.025$
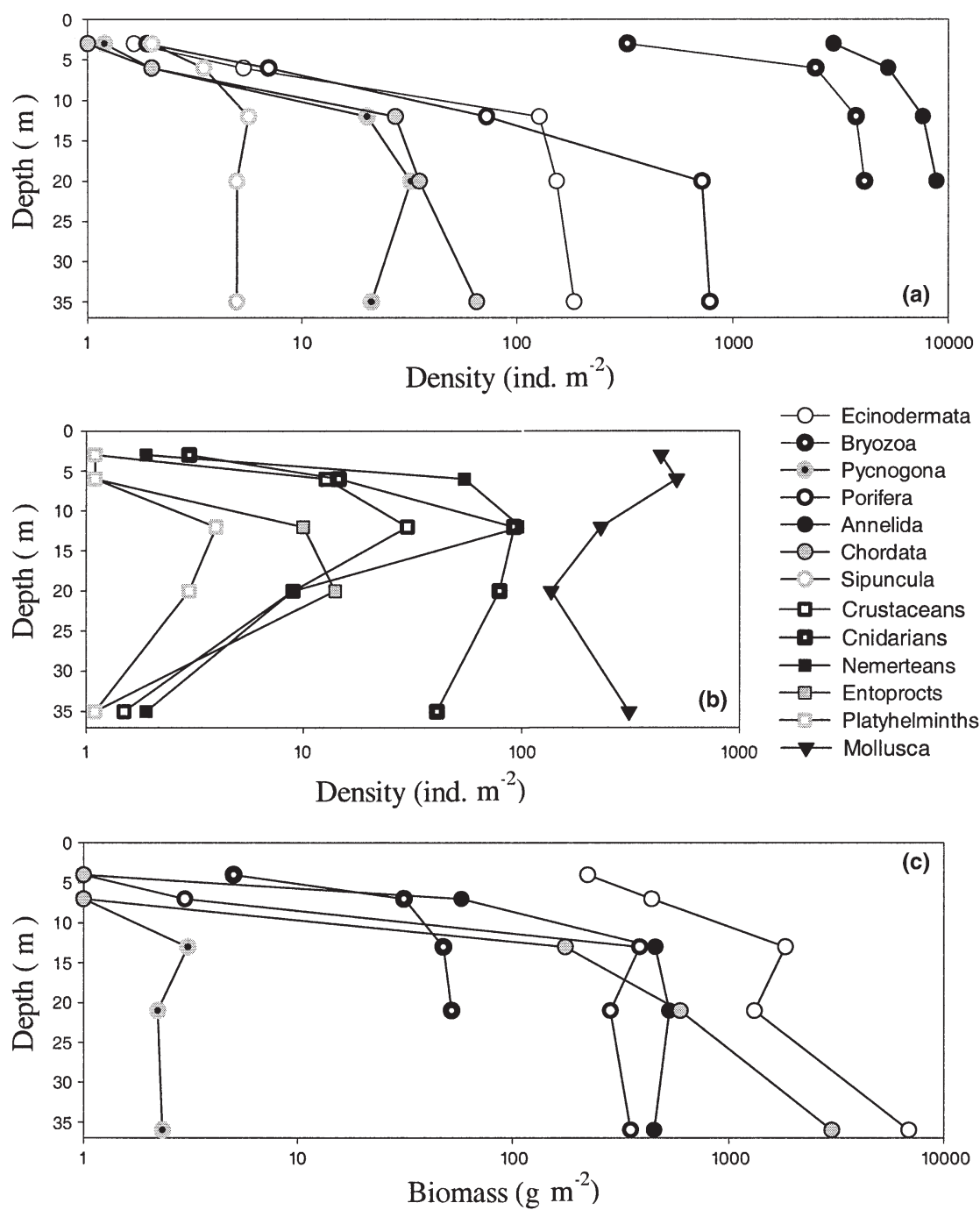


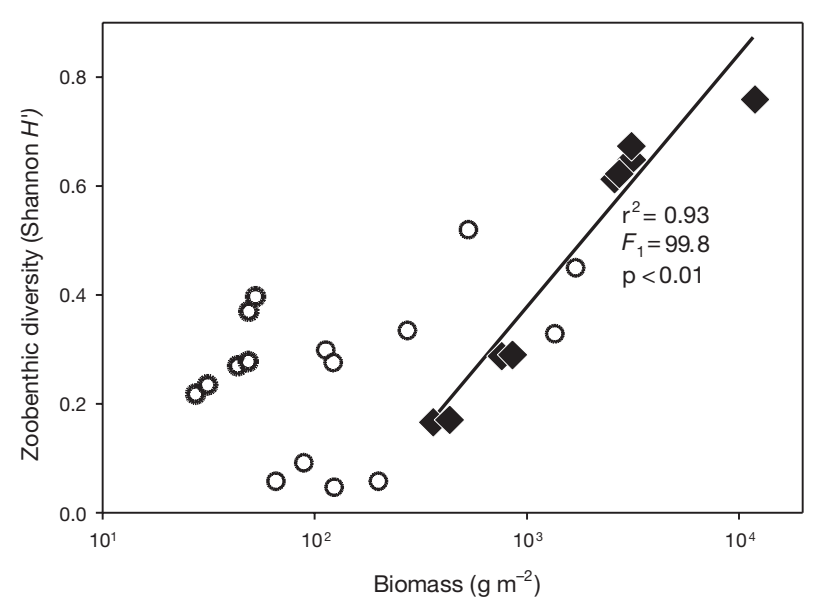

Fig. 4. Relationship between biomass and diversity at Adelaide Island. Bryozoans and echinoderms (symbols as in Fig. 3) were the only major taxa to show (weak) relationships between biomass and diversity. Overall (across taxa) relationship is shown as fitted line and is a 1st-order regression (fit and significance indicated on plot)

$100 \mathrm{gm}^{-2}$ ), phylum dominance changed with depth. Only bryozoa were recorded at $3 \mathrm{~m}$, and this phylum showed a steady increase with depth, reaching a maximum of $50 \mathrm{gm}^{-2}$ at $20 \mathrm{~m}$. Nemertean biomass peaked sharply between 6 and $12 \mathrm{~m}$, contributed to principally by 1 species, the large heteronemertean Parborlasia antarctica. At the lower biomasses (0.001 to $5 \mathrm{~g} \mathrm{~m}^{-2}$ ) 2 cryptic phyla (Entoprocta and Chelicerata) progressively increased biomass with depth to $20 \mathrm{~m}$. Both mites and pycnogonans were present though the latter contributed most of the individuals encountered in the study. The relationship between biomass and diversity was not simple. Only 2 of the major taxa showed consistent trends, but there was a strong link between total biomass and diversity (Fig. 4). Overall biomass and abundance was high at all depths relative to other polar or temperate reported values (Fig. 5).

The subtidal zone was quite distinct from the intertidal in that numbers of taxa, animal abundance, biomass and percentage cover were all highly increased. Although the increase of both numbers and biomass of fauna was gradual with depth and many taxa were present throughout the depth range sampled, distinct subtidal zonation was apparent. Three broad zones were recognised with characteristic macro/megabenthos and cryptofauna (Fig. 6). The high sublittoral (0 to $7 \mathrm{~m}$ ) was colonised by relatively high abundances of the non-homing limpet Nacella concinna and the cheilostome bryozoan Inversiula nutrix. Most other species (with the exception of Sterechinus neumayeri and spirorbid polycheates) were absent and total percentage cover in this region was below $20 \%$. The mid- sublittoral ( 7 to $20 \mathrm{~m}$ ) was characterised by a decrease in abundance of both $N$. concinna and I. nutrix and an increase of the Cyclostome bryozoan Tubulipora sp. and of macro-algal biomass. Percentage substratum cover in this zone increased to $90 \%$. The deepest sublittoral zone was characterised by increasing abundances of the holothurian Cucumaria antarctica and the demosponge Mycale acerata.

Within 1 species alone (the echinoid Sterechinus neumayeri), the tri-zonation of the site at Adelaide Island subtidal was clear (Fig. 7). In the shallows this species showed relatively low abundance $\left(<100 \mathrm{~m}^{-2}\right)$ but individuals were large (modal size $18 \mathrm{~mm}$ ) and, therefore, had high biomass. They were also the most conspicuous members of the community. At $10 \mathrm{~m} S$.
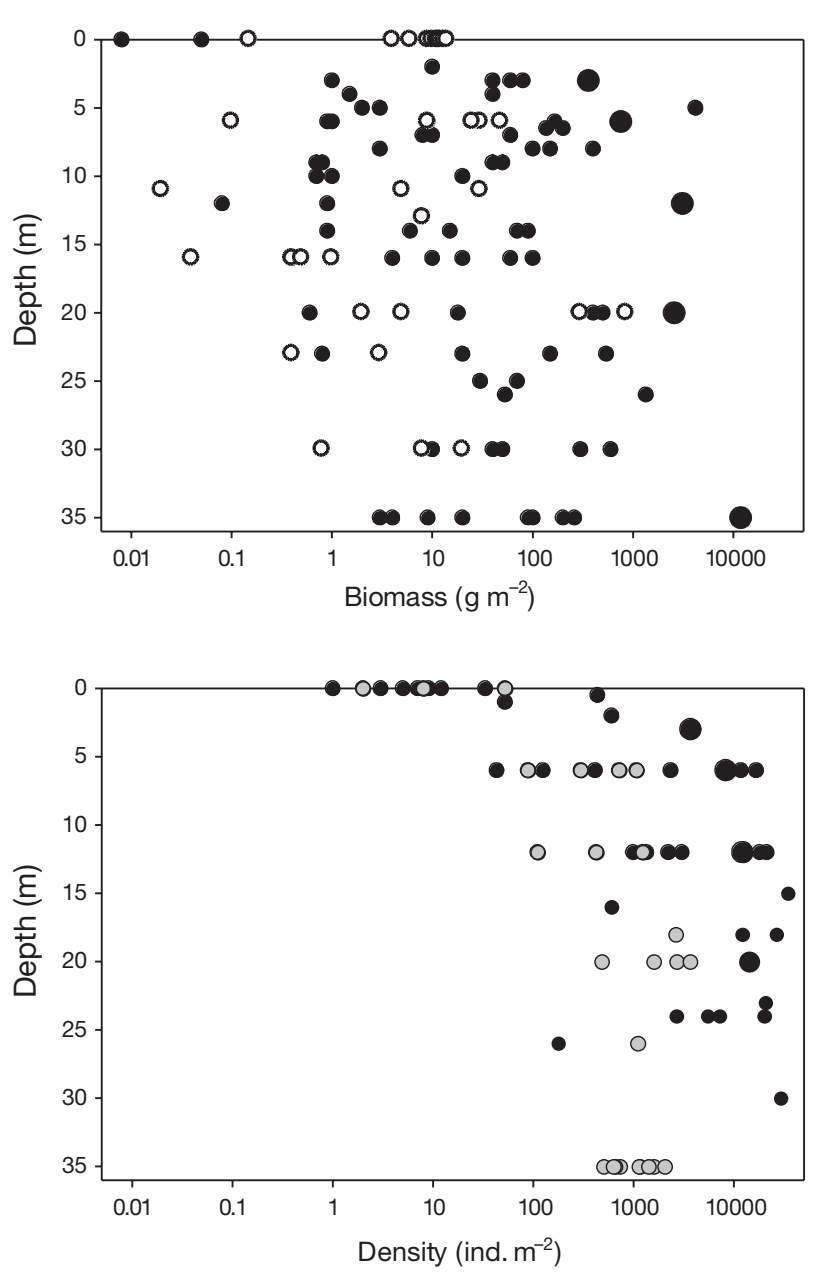

Fig. 5. Faunal biomass (upper) and abundance (lower) with depth and region. The symbols are: Antarctic data $(\bullet)$, temperate data $(\circ)$, arctic data $(\bullet)$ and data from current study (๑). Literature data are from Gruzov \& Pushkin (1970), Propp (1970), Richardson \& Hedgepeth (1977), Dayton (1990), Brey \& Clarke (1993), Arntz et al. (1994), Holte et al. (1996), Sjer et al. (2000), references therein and authors' unpubl. data 

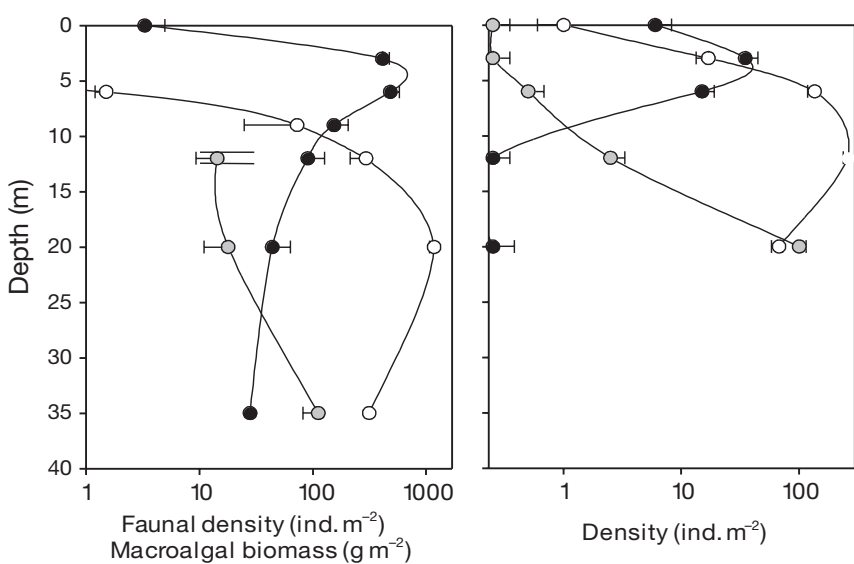

Fig. 6. Macrobiota (left): macroalgae (O), Cucumaria antarctica $(\bullet)$, Nacella concinna (๑): Cryptofauna (right):

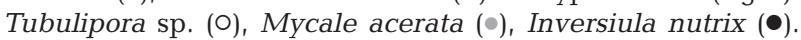
Data for taxa with $\bigcirc$ and $\bullet$ have significant quadratic functions $\left(\mathrm{r}^{2}>85.6 \%\right.$, ANOVA, $\left.F>18.8, \mathrm{p}<0.03\right)$. Curve for $N$. concinna fitted by eye; relationship for $I$. nutrix is a linear function $\left(\mathrm{r}^{2}>65 \%\right.$, ANOVA, $\left.F=16.7, \mathrm{p}<0.02\right)$

neumayeri peaked in biomass. At this depth they were abundant $\left(500 \mathrm{~m}^{-2}\right)$ but small (bimodal size peaks at 4 and $20 \mathrm{~mm}$ ). At $35 \mathrm{~m}$ depth $S$. neumayeri individuals were most numerous $\left(600 \mathrm{~m}^{-2}\right)$ but of smallest size (4 mm). The patterns within $S$. neumayeri were important, as were those to a lesser extent in the limpet Nacella concinna, in that they are also involved in structuring processes of other fauna, especially the bryozoans and annelids.

\section{DISCUSSION}

The number of at least 75 species found in a total sample area of $7.5 \mathrm{~m}^{2}$ in the intertidal and $2.75 \mathrm{~m}^{2}$ in the subtidal is high, but not exceptional, in terms of hard substratum species richness for any locality. Maughan \& Barnes (2000) used comparable sample methods on similar substratum at a temperate site, Lough Hyne in Ireland, renowned for its benthic richness. They found uniformly fewer (range 10 to 67 , mean 43) species at 3 to $18 \mathrm{~m}$ depth at mean sample areas of $2.747 \mathrm{~m}^{2}$. Similarly at Milos Island (Mediterranean Sea), also a site of established regional benthic richness (Morri et al. 1999), numbers of hard substratum shallow benthic species were comparable with Lough Hyne and lower than our polar study site. On the west Atlantic seaboard (Maine), Ojeda \& Dearborn (1989) encountered just 60 species from sampling an area 14 times the size of our sample site in the rocky subtidal. In contrast, typical temperate and tropical species richness in the littoral zone is probably an order of magnitude higher (e.g. McGuiness 1990, Maughan \& Barnes 2000). In comparison with Arctic sites the species richness we reported from Adelaide Island may be very high (see Dayton 1990, Arntz et al. 1994). For example, previously we have found 3 to 42 species per $\mathrm{m}^{2}$ across a similar depth range in Arctic Spitsbergen after sampling $10 \times$ the area of the present study (authors' unpubl. data). Holte et al. (1996) and Sjer et al. (2000) similarly report 8 to 42 species from comparable sample areas and depths from high arctic soft sediments. Although there is now an established marine diversity literature even in polar waters, methodological, area, depth or substratum differences do make hard comparisons difficult with other Antarctic (and other regional) data. Sublittoral species numbers reported for high Antarctic or Scotia Arc localities (Ushakov 1963, Gruzov \& Pushkin 1970, Propp 1970, Dayton et al. 1974, Arntz et al. 1994, Barnes 1995, Arnaud et al. 1998) are also lower. The cryptobenthic richness of exposed Antarctic Peninsula sites, such as Snow Island and South Georgia, reported by Barnes \& Arnold $(2001 \mathrm{a}, \mathrm{b})$ are much lower (both $<10$ species per $\mathrm{m}^{2}$ at 6 and $12 \mathrm{~m}$ depth). However sublittoral collections at subantarctic Marion Island yielded 64 to 106 species in $0.4 \mathrm{~m}^{2}$ area collections and a total of 203 species in $4 \mathrm{~m}^{2}$ (Becley \& Branch 1992). The really striking new values of richness in our study were, however, for the intertidal zone where 9 species were found. For many decades the land-air interface in Antarctica was considered virtually devoid of macroscopic life, other than very temporary visitors such as large vertebrates. Whilst 9 littoral species (in $7.5 \mathrm{~m}^{2}$ ) is still very low compared to non-polar waters (see

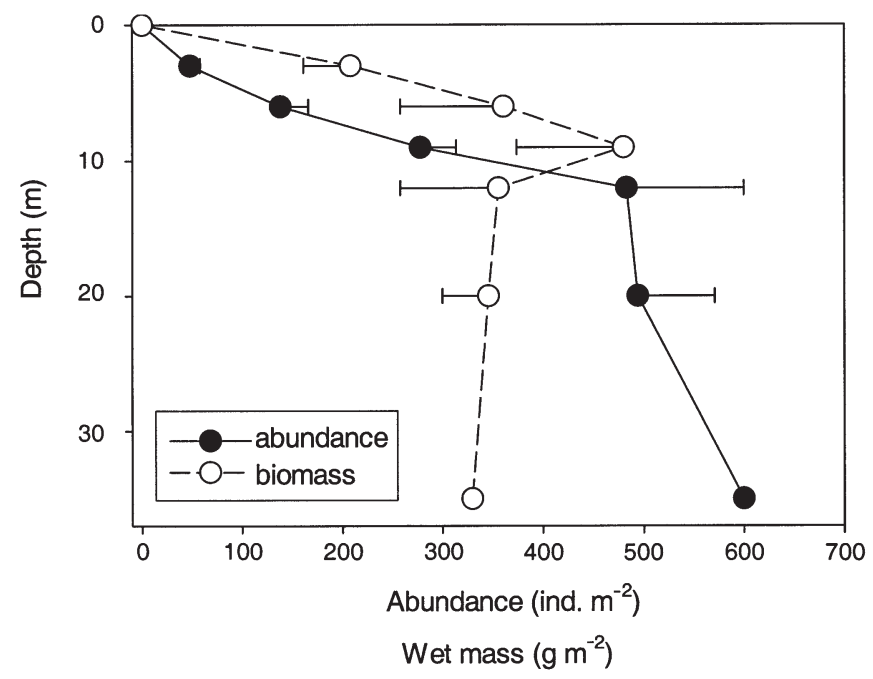

Fig. 7. Sterechinus neumayeri. Abundance and wetmass of echinoid with depth. Values are presented as mean with SD 
McGuiness 1990), it is probably a record for those in freezing seas. Barnes \& Arnold (2001b) found just 5 species in twice the area on the Signy Island littoral and $<5$ at several Antarctic Peninsula shore sites from 62 to $66^{\circ} \mathrm{S}$ (authors' unpubl. data). Even 9 littoral species were not the most notable feature in the data; this was the level of higher taxon richness. Ironically Antarctica and subzero waters have probably achieved most fame amongst ecologists for the absence, or near absence, of certain higher taxa. Despite the notorious rarity of balanomorph and decapod crustaceans, there must be few localities in which 16 animal phyla and 25 classes are represented in just $10 \mathrm{~m}^{2}$, as was the case reported here.

As in most environments the abundance of species and individuals was very unevenly distributed between higher-level taxa and functional groups, though colonial and unitary forms were nearly of numerical equivalence. If a large spatial scale is considered sessile and mobile species tend to be of similar importance in Antarctic benthic systems and cryptobenthic suspension feeders tend to be particularly numerous at high southern polar latitudes (Voß 1988). Our findings reflected this and suspension feeders certainly dominated absolute abundances. Such taxa tend to be particularly abundant in young assemblages like those on artificial panels (Schoener et al 1978), shells (Kay \& Keough 1981), coral and rock rubble (Hughes \& Jackson 1992) and polar substrata at most depths (Bullivant 1967, Winston \& Heimberg 1988, Galeron et al. 1992). Whilst suspension feeding and sessile nature are positive attributes to maintenance of low metabolic costs in a cold water, food limited environment and may aid establishment (Peck et al 1997), presence also requires opportunistic colonisation of space whenever it becomes available. Possession of pelagic larvae and variable timing of release or duration would enable an organism to have this recruitment potential. In contrast to the predictions of Thorson's rule (Mileikovsky 1971), Stanwell-Smith et al. (1998) found many pelagic larvae in the first detailed, year-round Antarctic study. Whether the diversity of pelagic (and particularly planktotrophic) larvae is high is debatable (Arntz \& Gili 2001) when the (high) richness of the sublittoral benthos at the location of Stanwell-Smith et al.'s (1998) study is taken into account. Unlike the surrounding benthos and recruits to artificial panels (StanwellSmith \& Barnes 1997), the larvae found by StanwellSmith et al. (1998) were not dominated by benthic suspension feeders. In fact, many of the individually highly successful species, such as Sterechinus neumayeri and Nacella concinna, have planktonic larvae.

Both the biomass and (to a lesser extent) the abundance values of macrobiota at Adelaide Island reported here are amongst the highest for any temper- ate or polar locality for the depths surveyed (Fig. 5). Only 1 ice-sheltered Antarctic site at Signy Island (White \& Robins 1972) and samples at 1 depth (5 m) at subantarctic Marion Island (Becley \& Branch 1992) had higher biomass. The highest fauna abundances we found (at $35 \mathrm{~m}$ ) are the only ones matching the same order of magnitude reported decades ago from McMurdo Sound (>118712 ind. $\mathrm{m}^{-2}$ ) by Dayton \& Oliver (1977). Sterechinus neumayeri and Nacella concinna were each almost entirely responsible for the dominance of their respective phyla in shallow water at Adelaide Island, with respect to biomass. The echinoid abundance and mass, as well as that of sponges (at greater depth), suggests significant commonality with the high Antarctic system at McMurdo Sound (Dayton et al 1970, 1974). Other features of the fauna (e.g. limpet proliferation in shallow water) and disturbance regime (rarity of anchor ice) bear more resemblance to characters of Signy Island in the maritime Antarctic. In terms of latitude and, therefore, light climate, Adelaide Island is intermediate (not in geographic relation) between these 2 well-studied localities (Signy Island and McMurdo Sound). In many ways Adelaide Island's biotic patterns seem to reflect this, possibly even in terms of biogeography (Clarke 1996, Barnes \& DeGrave 2000). It is possible that the intermediate position of ice disturbance and light climate experienced by the study locality, together with its geographic proximity to much of the continent's shelf area has resulted in the prolific higher taxon richness, diversity and abundance. Intermediate disturbancepromoted diversity (Connell 1978, Huston 1979) has rarely been invoked to systems at continent spatial scale (but see Gutt 2001), or at geological timescale, but there is no theoretical barrier why the same processes should not work at higher scales. Most of Antarctica's species are endemic but few of its genera are (though both vary with taxon; see Arntz \& Gili 2001), and all the classes and phyla are found widely elsewhere.

Zonation is a familiar and ubiquitous organisation of organisms by geography, topography and exposure. Due to the tight horizons and small spatial scale, vertical littoral zonation of algae and invertebrates tends to be the most obvious and the most studied by biologists. Although shore zonation is striking at temperate latitudes, winter freezing and the lack of macroorganisms results in the disappearance of the phenomenon approaching polar waters. On Tristan da Cunha $\left(37^{\circ} \mathrm{S}, 13^{\prime} \mathrm{W}\right)$, Gough $\left(41^{\circ} \mathrm{S}, 10^{\prime} \mathrm{W}\right)$ and Falklands $\left(51^{\circ} \mathrm{S}, 60^{\prime} \mathrm{W}\right)$ shores littoral zonation is marked in the fauna and flora (see de Villiers 1976). At or beyond the Polar Frontal Zone (PFZ), however, only changes in macroalgal distributions separate shore heights on the subantarctic islands of the Prince 
Edward archipelago, Kerguelen and South Georgia. No littoral zonation is apparent on any shores south of these islands. Floating ice, which scours polar shores and reduces littoral zonation, also, however, enhances sublittoral zonation. At Signy Island in the South Orkneys at $60^{\circ} \mathrm{S}$, sublittoral zonation is obvious (Barnes 1995) and in the South Shetlands $\left(62^{\circ} \mathrm{S}\right)$ an upper surf zone, a middle kelp zone and a more faunistically rich 15 to $30 \mathrm{~m}$ zone was noted by Gruzov \& Pushkin (1970). Further south, though, the benthos forms sharper patterns as described by Propp (1970) at the Haswell Islands $\left(66^{\circ} \mathrm{S}\right)$, at Adelaide Island in the present study, and in the Vestfold Hills by Kirkwood \& Burton (1988). Not only are these zones clear from assemblage constitution (Fig. 7) but also from characters of individual species spanning the bathymetric study range (Fig. 6). A similarly strong intensity of faunal depth horizons was previously reported at McMurdo Sound, a high Antarctic locality (Dayton et al. 1970). Thus the intensity of vertical zonation undergoes a graded change centred around the maximum extent of sea-ice front (Fig. 8). In the Arctic, littoral zonation becomes similarly reduced with latitude (Ellis \& Wilce 1961), but clear in the sublittoral (Dayton 1990), though equivalent changes occur at much higher boreal (than anti-boreal) latitude.

As species, which are both highly abundant and vertically partitioned, Sterechinus neumayeri and Nacella concinna are causative of zonation patterns per se but they also exert influences over other taxa intensifying zonation. Both are grazers and may be responsible for large-scale removal of many recruits and even some adult cryptofauna. Differential grazing pressure of numbers of both species may also be responsible for patterns in cryptofauna. This is neither a new phenomenon, geographically restricted nor unusual, but this is the first time it has been suggested for a polar locality. Both echinoids and limpets control many temperate subtidal and intertidal benthic systems (respectively) and have frequently, though sometimes debatably (Elner \& Vadas 1990), been described as keystone taxa because of this. Demonstration of such a role at Adelaide Island would not, however, be straightforward for several reasons. First, the role of these pivotal species would still be minor to zonation directly created by ice-scour and experimental exclusion of ice is considerably problematical. Second, community development in Antarctica takes place at least an order of magnitude slower than those in warm water (Stanwell-Smith \& Barnes 1997) so any experimental time-frame would need to work in decades. Finally, high Antarctic recruitment may be characterised by long periods of almost zero recruitment punctuated by stochastic pulses of settlement (Dayton 1989).

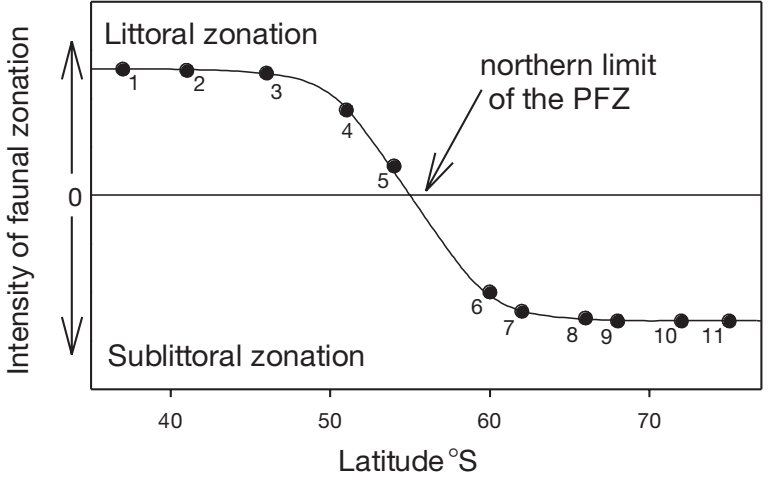

Fig. 8. Faunal zonation in relation to latitude and the position of the PFZ. Diagram is a schematic suggesting manner of change of intensity of zonation based on strength of littoral and sublittoral macrobiota patterns at sites at latitudes indicated by (1) Tristan da Cunha, (2) Gough Island, (3) Prince Edward Archipelago, (4) Falkland Islands, (5) South Georgia, (6) Signy Island, (7) South Sandwich Archipelago, (8) Haswell Island, (9) Adelaide Island, (10) Vestfold Hills and (11) McMurdo Sound

Acknowledgements. The authors would like to thank the diving and marine operations group at Rothera Research Station. We would also like to thank Lloyd Peck, Andrew Clarke and 4 anonymous referees for comments leading to a much improved manuscript.

\section{LITERATURE CITED}

Arnaud PM, Lopez CM, Olaso I, Ramil F, Ramos-Espla AA, Ramos A (1998) Semi-quantitative study of macrobenthic fauna in the region of the south Shetland Islands and the Antarctic Peninsula. Polar Biol 19:160-166

Arntz WE, Gili JM (2001) A case for tolerance in marine ecology: let us not put out the baby with the bathwater. Sci Mar 65(Suppl 2):283-299

Arntz WE, Brey T, Gallardo VA (1994) Antarctic zoobenthos. Oceanogr Mar Biol Annu Rev 32:251-303

Barnes DKA (1995) Sublittoral epifaunal communities at Signy Island, Antarctica. II. Below the ice foot zone. Mar Biol 121:565-572

Barnes DKA, Arnold RJ (2001a) A growth cline in encrusting benthos along a latitudinal gradient within Antarctic waters. Mar Ecol Prog Ser 210:85-91

Barnes DKA, Arnold RJ (2001b) Competition, sublethal mortality and diversity on Southern Ocean coastal boulder communities. Polar Biol 24:447-454

Barnes DKA, De Grave S (2000) Biogeography of southern polar bryozoans. Vie Milieu 50:261-274

Barnes RSK, Hughes RN (1999) An introduction to marine ecology. Blackwell Science, Oxford

Becley LE, Branch GM (1992) A quantitative SCUBA diving survey of the sublittoral macrobenthos at Subantarctic Marion Island. Polar Biol 11:553-563

Brey T, Clarke A (1993) Population dynamics of marine benthic invertebrates in Antarctic and subantarctic environments: are there unique adaptations? Antarct Sci 5: $253-266$

Brey T, Klages M, Dahm C, Gorny M and 6 others (1994) Antarctic benthic diversity. Nature 368:297 
Bullivant JS (1967) Ecology of the Ross Sea benthos. NZ J Mar Freshwat Res 32:49-75

Clarke A (1992) Is there a latitudinal diversity cline in the sea? Trends Ecol Evol 7:286-287

Clarke A (1996) The distribution of Antarctic marine benthic communities. Antarct Res Ser 70:219-230

Clarke A, Lidgard S (2000) Spatial patterns of diversity in the sea: bryozoan species richness in the north Atlantic. J Anim Ecol 69:799-814

Connell JH (1978) Diversity in tropical rain forests and coral reefs. Science 199:1302-1310

Crame JA (2000) Evolution of taxonomic diversity gradients in the marine realm: evidence from the composition of recent bivalve faunas. Paleobiology 26:188-214

Dayton PK (1989) Interdecadal variation in an Antarctic sponge and its predators from oceanographic climate shifts. Science 245:1484-1486

Dayton PK (1990) Polar benthos. In: Smith WO (ed) Polar oceanography. Academic Press, London, p 631-685

Dayton PK, Oliver JS (1977) Antarctic soft bottom benthos in oligotrophic and eutrophic environments. Science 197:55-58

Dayton PK, Robilliard GA, Paine RT (1970) Benthic faunal zonation as a result of anchor ice at McMurdo Sound, Antarctica. In: Holgate MW (ed) Antarctic ecology, Vol 1. Academic Press, London, p 244-257

Dayton PK, Robilliard GA, Paine RT, Dayton LB (1974) Biological accommodation in the benthic community at McMurdo Sound, Antarctica. Ecol Monogr 44:105-128

de Villiers AF (1976) Littoral ecology of Marion and Prince Edward islands (Southern Ocean). S Afr Tydskr Antarkt Nav 1-40

Ellis DV, Wilce RT (1961) Arctic and subarctic examples of intertidal zonation. Arctic 14:224-235

Elner RW, Vadas RL (1990) Inference in ecology: the sea urchin phenomenon in the northwestern Atlantic. Am Nat 136:108-125

Galéron J, Herman RL, Arnaud PM, Arntz WE, Hain S, Klages M (1992) Macrofaunal communities on the continental shelf and slope of the southeastern Weddell Sea, Antarctica. Polar Biol 3:283-290

Gallardo VA, Castillo J (1969) Quantitative benthic survey of the infauna of Chile Bay (Greenwich Island, South Shetland Island). Gayana 16:3-18

Gray JS (2001) Marine diversity: the paradigms in patterns of species richness examined. Sci Mar 65:41-56

Gruzov EN, Pushkin AF (1970) Bottom communities of the littoral region of the upper sublittoral of Enderby Land and the South Shetland Islands. In: Holdgate M (ed) Antarctic ecology. Academic Press, London, p 235-238

Gutt J (2001) On the direct impact of ice on marine benthic communities, a review. Polar Biol 24:553-564

Gutt J, Starmans A (2001) Quantification of iceberg impact and benthic recolonisation patterns in the Weddell Sea (Antarctica). Polar Biol 24:615-619

Gutt J, Starmans A, Dieckmann G (1996) Impact of iceberg scouring on polar benthic habitats. Mar Ecol Prog Ser 137: 311-316

Holte B, Dahle S, Gullikson B, Naes K (1996) Some macrofaunal effects of local pollution and glacier induced sedimentation, with indicative chemical analyses, in the sediments of two arctic fjords. Polar Biol 16:549-557

Hughes DJ, Jackson JBC (1992) Distribution and abundance of cheilostome bryozoans on the Caribbean reefs of central Panama. Bull Mar Sci 51:443-465

Huston M (1979) A general hypothesis of species diversity. Am Nat 113:81-101

Jablonski D, Bottjer DJ (1990) Onshore-offshore trends in marine invertebrate evolution. In: Ross RM, Allmon WD (eds) Causes of evolution: a paleontological perspective. University of Chicago Press, Chicago, p 21-75

Kay AM, Keough MJ (1981) Occupation of patches in the epifaunal communities on pier pilings and the bivalve Pinna bicolour at Edithburgh, South Australia. Oecologia 48:123-130

Kirkwood JM, Burton HR (1988) Macrobenthic species assemblages in Ellis Fjord, Vestfold Hills, Antarctica. Mar Biol 97:445-457

Klöser H, Ferreyra G, Schloss I, Mercuri G, Laturnus F, Curtosi A (1993) Seasonal variation of algal growth conditions in sheltered Antarctic bays: the example of Potter Cove (King George Island, South Shetlands). J Mar Syst 4: 289-301

Klöser H, Mercuri G, Laturnus F, Quartino ML, Wiencke C (1994a) On the competitive balance of macroalgae in Potter Cove (King George Island, South Shetlands). Polar Biol 14:11-16

Klöser H, Ferreyra G, Schloss I, Mercuri G, Laturnus F, Curtosi A (1994b) Hydrography of Potter Cove, a small fjordlike inlet on King George Island (South Shetlands). Estuar Coast Shelf Sci 38:523-537

Maughan B, Barnes DKA (2000) Epilithic boulder communities of Lough Hyne, Ireland: the influences of water movement and sediment. J Mar Biol Assoc 80:767-776

McCook LJ, Chapman ARO (1997) Patterns and variations in natural succession following massive ice-scour of a rocky intertidal seashore. J Exp Mar Biol Ecol 214:121-147

McGuiness K (1990) Physical variability, diversity gradients and the ecology of temperate and tropical reefs. Aust $\mathrm{J}$ Ecol 15:465-476

Mileikovsky SA (1971) Types of larval development in marine bottom invertebrates, their distribution and ecological significance: a re-evaluation. Mar Biol 10:193-213

Morri C, Bianchi CN, Cocito S, Peirano A and 7 others (1999) Biodiversity of marine sessile epifauna at an Aegean island subject to hydrothermal activity: Milos, eastern Mediterranean Sea. Mar Biol 135:729-739

Ojeda FP, Dearborn JH (1989) Community structure of macroinvertebrates inhabiting the rocky subtidal zone in the Gulf of Maine: seasonal and bathymetric distribution. Mar Ecol Prog Ser 57:147-161

Peck LS, Rhodes MC, Curry GB, Ansell A (1997) Physiology. In: Kaesler RL (ed) Treatise on invertebrate palaeontology. Part $\mathrm{H}$ Brachiopoda. The Geological Society of America, Boulder, CO, and the University of Kansas, Lawrence, KA p 213-240

Propp MV (1970) The study of bottom fauna at Haswell Islands by SCUBA diving. In: Holdgate $M$ (ed) Antarctic ecology. Academic Press, London, p 239-241

Rauschert M (1991) Ergebnisse der faunistischen Arbeiten im Benthal von King George Island (Südshetlandinseln, Antarktis). Ber Polarforsch 76:1-75

Richardson MD, Hedgepeth JW (1977) Antarctic soft bottom, macrobenthic community adaptations to a cold, stable, highly productive glacially affected environment. In: Llano GA (ed) Adaptations within Antarctic ecosystems. The Smithonian Institution, Washington, p 181-196

Roy K, Jablonski D, Valentine JW, Rosenberg G (1998) Marine latitudinal diversity gradients: tests of causal hypotheses. Proc Natl Acad Sci USA 95:3699-3702

Sanders HL (1968) Marine benthic diversity: a comparative study. Am Nat 102:243-282

Schoener A, Long ER, DePalma JR (1978) Geographic variation in artificial island curves. Ecology 59:367-382

Sejr MK, Jensen KT, Rysgaard S (2000) Macrobenthic community structure in a high-arctic East Greenland fjord. Polar Biol 23:792-801 
Stanwell-Smith D, Barnes DKA (1997) Benthic community development in Antarctica: recruitment and growth on settlement panels at Signy Island. J Exp Mar Biol Ecol 212:61-79

Stanwell-Smith D, Peck LS, Clarke A, Murray AWA, Todd CD (1998) The distribution, abundance and seasonality of pelagic marine invertebrate larvae in the maritime Antarctic. Phil Trans R Soc Lond B 353:1-14

Stehli FG, Wells JW (1971) Diversity and age patterns in hermatypic corals. Systematic Zool 20:115-126

Stehli FG, McAlester AL, Helsey CE (1967) Taxonomic diversity of recent bivalves and some implications for geology. Geol Soc Am Bull 78:455-466

Tucker JM (1988) Temporal distribution and brooding behaviour of selected benthic species from the shallow marine waters off the Vestfold Hills, Antarctica. Hydrobiologia 165:151-159

Editorial responsibility: Otto Kinne (Editor), Oldendorf/Luhe, Germany
Ushakov PV (1963) Some characteristics of the distribution of the bottom fauna off the coast of east Antarctica. Inf Byull Sov Antarkt Eksped 40:5-13

Valentine JW (1973) Evolutionary paleoecology of the marine biosphere. Prentice Hall, Englewood Cliffs, NJ

Voß J (1988) Zoogeographie und Gemeinschaftsanalyse des Makrozoobenthos des Weddellmeeres (Antarktis). Ber Polarforsch 45:1-145

White MG, Robins MW (1972) Biomass estimates from Borge bay, Signy Island, South Orkney Islands. Br Antarct Surv Bull 31:45-50

Winston JE, Heimberg BF (1988) The role of bryozoans in the benthic community at Low Island, Antarctica. Antarctic J US 21:188-189

Zamorano JH (1983) Zonacion y biomasa de la macrofauna betonica en Bahia South, Archipelago de palmer, Antarctica. Inst Antarctico Chil Ser Cient 30:27-38

Submitted: July 22, 2002; Accepted: September 26, 2002 Proofs received from author(s): January 6, 2003 